\title{
Küresel Sağlık Politikasının Aktörleri
}

\author{
Burcu Gediz Oral a, b, Tuğba Arpazlı Fazlılar c
}

\section{Özet}

Küresel sağlık politikası oluşturma alanları kamusal alanlardan ulusötesi kâr amaçlı sektörü içeren alanlara doğru kaymaktadır. Bu süreçte bulaşıcı olmayan hastalıklar ve sağlık sistemlerini geliştirme konuları ihmal edilmiştir. Öte yandan bulaşıcı hastalıklar küresel sağlık öncelikleri olarak gündeme gelmiştir. Günümüzde sağlık sorunlarının üstesinden gelmeye yönelik yaklaşımlarda teknolojik çözümlere daha sıcak bakılmaktadır. Bunun sonucu olarak ticaret ve sanayi çıkarları daha fazla ön plana çıkmaktadır. Bu nedenle küresel sağlık politikası günden güne parçalanarak dikey bir yapıya dönüşmüştür. Bu çalışmada küresel sağlık politikası aktörleri, küresel sağlık öncelikleri ve sağlık önceliklerini ele alma araçları olmak üzere üç konu ele alınmıştır. Çalışmada, uluslararası örgütlerin, kamu özel sektör işbirliklerinin (KÖSİ ${ }^{1}$ ) ve sivil toplum örgütlerinin düşük ve orta gelirli ülkelerde sağlık hizmetleri ve sağlık politikası hazırlama konusundaki değişen politika yönergeleri deskriptif yöntemle analiz edilmektedir.

\section{Actors of Global Health Policy}

\begin{abstract}
Areas of global health policy-making are shifting from public sphere to areas that include transnational profit-making sectors. In this process, non-infectious diseases and health system development issues have been neglected. On the other hand, infectious diseases have emerged as global health priorities. Nowadays, technological solutions are taken care of in approaches to overcome health problems. As a result of this trade and industry interests became more prominent. Therefore global health policy has turned into a vertical structure. In this study, three topics were discussed: global health policy actors, global health priorities, and instruments to defined health priorities. In this study, the changing policy guidelines of international organizations, public private partnerships (PPPs) and non-government organizations in preparing health care and health policy in low and middleincome countries are analyzed bu using descriptive method.
\end{abstract}

Anahtar Kelimeler

Küresel Sağlık

Uluslararası Kuruluşlar

Küresel Kamu Özel Sektör

İşbirlikleri

Küresel Kamusal Mallar

Makale Hakkında

Geliş Tarihi: 03.04.2019

Kabul Tarihi: 20.11.2019

Doi: 10.18026/cbayarsos.548710

Keywords

Global Health

International Organizations

Global Public Private

Partnerships

Global Public Goods

About Article

Received: 03.04.2019

Accepted: 20.11.2019

Doi: 10.18026/cbayarsos.548710

a İletişim Yazarı: burcu.gediz@cbu.edu.tr

b Doç. Dr., Manisa Celal Bayar Üniversitesi, Uygulamalı Bilimler Fakültesi, Şehit Prof. Dr. İlhan Varank Yerleşkesi, ORCID: 0000-0001-7096-9288.

c Arş. Gör., Manisa Celal Bayar Üniversitesi, Uygulamalı Bilimler Fakültesi, Şehit Prof. Dr. İlhan Varank Yerleşkesi, ORCID: 0000-0001-8838-8959. 


\section{Giriş}

Dünyanın dört bir yanında çevre sorunları, uluslararası terör ve bulaşıcı hastalıklar gibi tek bir aktör tarafından çözülemeyecek tehditler vardır. Bu sorunlar küreselleşmenin yol açtığ1 genel zorluklarla, vatandaşların davranışlarıyla ve aynı zamanda ulusal devletlerin otoritesi ve meşruluğuyla artmaktadır. Bu bağlamda asıl sorun, hangi zorlukların ele alınacağı, hangi aktörün burada görev alması gerektiği ve hangi araçların kullanılabileceği olmaktadır. Bu zorlukları yönetmek için hangi tür yönetişimin gerekli olduğu belirlenirken, dikkat edilmesi gereken unsur, geleneksel bir devletin tek başına hedeflere ulaşmasının neredeyse imkânsız olduğudur. Bu noktada, ulusal aktörlerin geleneksel yaklaşımını genişleten çözümler gerekli olabilir. Bununla birlikte bu tehditlerde, genel güvenlik, sağlık ya da politik istikrar gibi altyapıların sağlanmasıyla bireylerin ve toplumların yararının hedeflenmesinin önemi inkâr edilemez (Gediz Oral ve Arpazlı Fazlılar, 2018; Schomaker, 2017: 121-122).

Doğası gereği, sağlık sorunları dünyanın karşı karşıya olduğu diğer sorunlara nazaran biraz daha özeldir: Bir yandan, hastalıkların kontrolü, bu tehditler düzgün bir şekilde hedeflenmeden önce yeni ilaçlar veya aşıların bulunması gerektiğinden, araştırma ve teknolojiye çok bağlıdır. Diğer yandan bu zaman, beceri ve yatırım gerektiren bir süreçtir. Ancak bu yatırımların geri dönüşü, ürünün nihai onayına kadar açık değildir (Schomaker, 2017: 130). Sağlık ekonomistleri, sağlık hizmetlerinin sunumunun genellikle bir piyasa başarısızlığıyla sonuçlandığını kabul etmektedirler. Piyasa başarısızlığı, piyasa mal ve hizmetlerinin verimli bir şekilde tahsis edilmediği durumlarda ortaya çıkmaktadır. Bu durumda hükümetler, kamu mallarını doğrudan vergilendirmeyle ya da lisans yoluyla finanse ederek sunmaya çalışmaktadır (Smith, 2003: 475). Hükümetler, özellikle gelişmekte olan ülkelerde, genel nüfus sağlı̆̆1 için mali veya örgütsel kapasiteden yoksundurlar. Hükümetin başarısızlığ ${ }_{1}$ sonucunda sağlık ürünleri ve hizmetleri yetersiz kalmaktadır. Bu nedenle, bu toplulukların sağlığını korumak için diğer aktörlerin desteğinin alınması gerekmektedir (Brown, 2008).

II. Dünya Savaşı'ndan sonra, Dünya Sağlık Örgütü (WHO), uluslararası sağlık çalışmaları konusunda koordinasyonu sağlama göreviyle kurulmuştur. 1980'li yıllardan beri, neo-liberal politikaların ortaya çıkması ve küreselleşmeyle birlikte, sağlığa bütünsel yaklaşım ortadan kalkmış, dikkat sadece hastalıkların kontrolüne odaklanmış, kamunun sistem içindeki rolü sorgulanmış ve düzenleyici rolü ön plana çıkartılmıştır (Gediz Oral, 2016a). Dünya Bankası (WB) bu durumdan giderek artan bir şekilde etkilenmiş, WHO'nun düzenli bütçesi dondurulmuş ve örgüt zengin ülkelerin ve diğer aktörlerin "gönüllü" katkılarıyla ilerlemeye başlamıştır. 2000'li yılların başında, yeni güçlü aktörlerin ortaya çıkmasıyla birlikte, küresel sağlık yönetişimi farklı ilgi ve güçlere sahip oyuncularla dolmuştur. Hem Birleşmiş Milletler'e (UN) hem de sisteme dâhil olan aktörler (özel sektör, G8, KKÖSİ-Küresel KÖSİ-, küresel politik ve ekonomik çevre), küresel politika yapıcılığını etkileyen unsurlar haline gelmiş, sağlığın ticarileştirilmesi yönünde zorlayıcı tavırlara bürünmüşlerdir (Missoni, 2008). Mevcut örgütsel ortamların karmaşıklığı, Uluslararası Organizasyonlar (IO'lar), ulusal devletler ve özel sektör tarafından oluşturulan işbirliklerinin genel olarak bir analizini yapmayı imkânsızlaştırmaktadır. Bu çalışmadaki amacımız, teorik bir bakış açısıyla küresel sağlık aktörlerinin hangi şartlar altında sağlık hizmetlerinin sağlanmasında yer aldığının ve IO'ların amaçlarının etkin bir şekilde sağlanmasına ne kadar katkıda bulunduğunun tespitidir. Bu amaç çerçevesinde çalışma deskriptif yöntemle ele alınacaktır. 


\section{Küresel Sağlık Öncelikleri}

1977 yılında, Dünya Sağlık Asamblesi "Herkes için Sağlık 2000" hedefini benimsemiştir. Kararı izleyen yıl 1978'de Kazakistan'ın Başkenti Alma Ata'da toplanan Uluslararası Sağlık Konferansı'nda 2000'li yılların sağlık politikasını şekillendirecek olan Alma Ata Deklarasyonu kabul edilmiştir (Topkaya, 2016: 714). Deklarasyon, Temel Sağlık Hizmetlerini, her ülkenin sağlık sisteminin ayrılmaz bir parçası olarak değil, aynı zamanda sosyal ve ekonomik kalkınmanın tamamı olarak, eşitlik ve toplum katılımına dayalı bir bakış açısıyla, en iyi strateji olarak belirlenmiştir. Bu, neo-liberal politikaların ortaya çıkması ve hüküm sürmesi, bütünsel bir öneriyi önemli sistemsel toplumsal çıkarımlarla çözme ihtiyacı ile de uyumlu olmuştur. Fakat zamanla dikkatler sağlıktan uzaklaştırılmış ve tek tek hastalıkların kontrolüne odaklanmıştır. Bu durum, IO'ların ve ikili bağışçıların² güçlü etkisi altında, kısa zamanda "dikey programlar" da sağlık sistemlerinin yeniden düzenlenmesi, kamu sağ lığı faaliyetlerinin parçalanması, maliyetlerin çoğalması ve kaynak israfıyla sonuçlanmıştır. Sağlık-odaklı olmayan bu tür bir yaklaşım, hastalıktan ziyade, ana donör ülkelerin ve kurumların politik ve idari amaçları ile daha uyumlu olmuştur. Tüm insanların sağlığı, dünya barışı ve güvenliği için vazgeçilmez bir şarttır. Farklı ülkelerde sağlık ve hastalıkların kontrol altına alınmasında eşit olmayan imkânlar, sağlığın ortak bir tehlike olarak ele alınmasının gerekliliğini ortaya çıkarmıştır. Bu durum hem sağlıkla ilgili konuların küresel doğasını hem de uluslararası ilişkiler ile bağlantılarını açıkça ortaya koymuştur. Dikey programlar piyasa stratejilerine ve "sosyal pazarlamaya" daha iyi uyum sağlamış ve göreceli olarak ucuz ancak oldukça göze çarpan kampanyaların ardında, insanların sağlık koşullarını iyileştirmek için gerçek bir siyasi iradenin yokluğunu maskelemeye hizmet etmiştir (Missoni, 2008).

Küresel sağlık öncelikleri çeşitli süreçler, çeşitli aktörler ve çeşitli forumlarda tanımlanmış, HIV / AIDS, tüberküloz ve sıtma, çeşitli forumlarda tartışılmış, Birleşmiş Milletler'in (UN) yanı sıra G8, Dünya Bankası (WB), Dünya Ekonomik Forumu ve Avrupa Komisyonu tarafından ele almıştır. Binyıllık Kalkınma Hedefleri (2000), uluslararası kuruluşlar arasında yapılan istişarelerin bir ürünüdür, aynı zamanda UN tarafından da benimsenmiştir. Binyıllık Kalkınma Hedefleri çocuk ölümleri, anne sağlı̆̆ı, HIV / AIDS, sıtma ve diğer hastalıklar şeklinde üçü sağlık odaklı olmak üzere sekiz hedefe sahiptir. Küresel ölüm ve hastalık yükü hesaplamalarına göre, yukarıda belirtilen öncelikler aslında, Sahra-altı Afrika'daki ölümleri ve kötü sağlığı temsil etmektedir. Ancak başka herhangi bir bölgedeki sağlıksızlığı temsil etmemektedir. $\mathrm{Bu}$ hedefler küresel sağlıksızlığın üçte birinden daha az kısmını kapsamaktadır. Günümüzde, bulaşıcı olmayan hastalıklar, gelişmekte olan ülkelerde sağlıksızlığın temel nedenidir ve önemli bir hızla artmaktadır. Bu hastalıklar bütün sosyoekonomik grupları etkilemektedir ve birçok durumda en büyük risk toplumun en fakir kesimlerinde olmaktadır (Ollila, 2005).

Bununla birlikte, dünyada örneğin pandemiden ${ }^{3}$ etkilenmemiş hiçbir ülke ya da bölge yoktur. Dahası, hastalığın küreselleşmesi HIV/AIDS ile sınırlı değildir. Sıtma, tüberküloz ve diğer bulaşıcı hastalıklarda görülen salgınlar, sağlık altyapıları üzerinde muazzam baskılar yaratmakta, hastalık ve ölüm artışlarını tetiklemektedir. SARS ve kuş gribi gibi bulaşıcı hastalıkların salgın oranlarına ulaşma potansiyeli her zaman bulunmaktadır. Gelişmiş ve gelişmekte olan ülkelerde kardiyovasküler hastalıklar ve kanser dâhil olmak üzere bulaşıcı olmayan hastalıklar da endişe verici oranlarda artmaktadır (Missoni, 2008).

Sağlık yönetimi geleneksel olarak ulusal hükümetlerin alanı olmuştur. Hükümetler sağlık sistemlerini düzenler ve gerektiğinde, sağlık ve hastalıkları kendi sınırları içinde izleme ve 
kontrol etme amacıyla WHO gibi uluslararası örgütlerle koordine ederler. Uluslararası Sağlık Yönetişimi (IHG), WHO gibi kuruluşlar aracılığıyla, hastalık salgınlarını izleme ve bunlara yanıt verme, sağlık raporlaması için standartlar oluşturma ve küresel sağlık konularında ülke bilgisi ve teknik uzmanlık için bir veri tabanı oluşturma konusunda uzun bir geçmişe sahiptir. IHG'nin temel dayanağı, devletlerin sağlık sorumluluğu taşımasıdır. Bununla birlikte, küreselleşme sağlığa yeni zorluklar getirmiş ve küresel sağlık yönetişiminin ortaya çıkan biçimlerinin ardındaki itici güç olmuştur. Zacher (1999), küreselleşmenin devletlerin kendi halklarının sağlığını sağlama kapasitesini azalttığını savunmaktadır. Nüfusun, bilginin, ürünlerin, dışsallıkların artan akışları, hane halkı için sağlık risklerinde artışlar yaratır ve böylece ulusal sağlık yönetimi için yeni zorluklar oluşturur. Buna ek olarak küreselleşmenin devletler içinde ve ülkeler arasında ekonomik eşitsizlikleri ve yoksulluğu devam ettirdiği hatta şiddetlendirdiği de iddia edilmiştir (Dodgson vd., 2002). Bu nedenle küreselleşmenin HIV/AIDS, sıtma, tüberküloz ve benzeri hastalık salgınlarının şiddetlenmesine yol açtığı iddia edilebilir. Birleşmiş Milletler Programı (UNAIDS/WHO), bulaşıcı hastalıkların bazı ülkelerde ve bölgelerde görülme sıklığı ve yaygınlık oranlarında düşüşler olsa da, henüz bu düşüşlerin istikrarlı olmadığını bildirmiştir (Brown, 2008; Missoni, 2008).

Dünyanın her yerinde hükümet kurumları, sivil toplum örgütleri, bilim adamları ve ilaç firmaları HIV / AIDS, sıtma ve küresel sağlık yükünün çoğunluğunu oluşturan tüberküloz gibi halk sağlığı tehditleriyle mücadele etmek için işbirliği yapmaktadır. Batı Afrika'daki Ebola'nın mevcut durumu bu tehdidi göstermektedir. Bu ve diğer hastalıklara bir süredir odaklanılmasına rağmen, bugüne kadar, uluslararası toplum bu tehditleri hafifletmek için gerekli olan tıbbi tedariği geliştirememiştir. Bu sorunun IO'ların yükümlülüğü olup olmadığ sorusu devam etmektedir (Schomaker, 2017). Ulusal öncelikler genellikle küresel önceliklerden farklı olduğundan, meseleyi küresel kamusal mallar etrafında düşünmek bunu bir başlangıç noktası olarak kabul etmek gereklidir. Küresel programlara ve küresel önceliklere daha fazla vurgu yapılması, ulusal egemenlik ve yetkilendirme açısından sorun yaratmaktadır (Ollila, 2005). Küresel sağlık sorunları birçok durumda küresel kamu malları için özel örnekler olarak görülebilir.

\section{Küresel Kamusal Mal Olarak Sağlık}

Bir malın kamusal mal olup olmadığını belirlemek için "tüketimde rekabet" ve "ödeme yapmayan kullanıcıların dışlanabilirliği" olmak üzere iki gösterge kullanılır. Yüksek rekabet derecesi, bir kullanıcının tüketiminin, başka bir kişi için kullanım şansını etkileyebileceğini gösterirken, dışlanabilirlik ise maliyete katılmayanın tüketimden ve faydadan mahrum edilmesi anlamına gelmektedir. Rekabet ve dışlanabilirlik varsa, mal özel bir mal olarak sinıflandırılabilir (Schomaker, 2017). Bu bağlamda, sunulan malların coğrafi kapsamı önemlidir. Kamu malları, vatandaşlarının çıkarları için ulusal hükümetler tarafından sağlanır ve malın potansiyel kullanıcıları vergiye tabi olarak malın finansmanı için ödemede bulunur. Ancak, güvenlik ve sağlık gibi bazı kamu mallarının faydası veya zararı tek bir ulus ya da bölgenin sınırlarında kalmadığından bu mallar, belirli bir coğrafi bölge veya toplumla sınırlı olmayan, dünya çapında yayılan yararlar veya olumsuz dişsallıklar üretir (Nordhaus 2005). Dolayısıyla, küresel kamusal mallar (KKM) olarak tanımlayabileceğimiz bu mallar ulusal sınırları aşan kamu mallarıdır ve tüketimlerinde rekabet ve dişlamadan söz edilemez (Kirmanoğlu vd, 2006: 170; Schomaker, 2017: 123). 
KKM sinırları aşan, tüm ülkelere, nüfus gruplarına ve nesillere fayda veya zarar sağlayan mallardır (Yalçın, 2009: 290; Türmen, 1999: 9). KKM arasında temiz hava, barış ve güvenlik de vardır. Bunlar gibi KKM'ler uluslararası anlaşmalar, protokoller ve diğer toplu eylem biçimleriyle sağlanabilir. Kamu mallarını sağlamak için vergi alma gücüne sahip devlete eşdeğer bir kurum küresel düzeyde mevcut değildir (Brown, 2008).

Hizmet sunumundaki verimsizlikler, "geleneksel” kamu mallarına kıyasla KKM’lar için daha fazla kabul edilebilir. Çünkü bunların sağlanması yer ve zaman bakımından daha geniş alana yayılır. Bir KKM sadece mevcut nesillere değil, aynı zamanda daha sonraki nesillere geleneksel kamu mallarından daha yüksek bir düzeyde fayda sağlayabileceği için de önemlidir. Bu özelliklere dayanarak, KKM'nin verimli üretimi, küresel bir işbirliğini ya da "kolektif eylemi" gerektirmektedir (Nordhaus 2005). Bu bağlamda ana zorluk, doğrudan kamu mallarını finanse edebilecek ve/veya sağlayabilecek bir idarenin eksikliğine rağmen kolektif eylemi sağlamaktır (Smith ve MacKellar 2007). Bu boşluk, belirli IO'lar tarafından kapatılabilir. Bu da, doğası gereği temsil ve yürütme gücüne sahip aktörleri olan kolektif eylemleri mümkün kılacaktır. KKM'lerin IO'lar veya diğer işbirliği rejimleri gibi küresel aktörler tarafından sağlanması bir ihtiyaç ve ekonomik gereklilik olabilir (Schomaker, 2017: 124) .

Bazı sorunların küresel etkilere sahip olabileceği gerçeği, bu sorunların çözümünü hedefleyen mal ve hizmetlerin sağlanması anlamında önlemler söz konusu olduğunda birlikte hareket etme kararı için yeterli bir kriter değildir. Her küresel etki, küresel eylemin gerekliliğini ortaya çıkarmaz; doğasında hiçbir otomatizm yoktur. Aksine mesele, eylemin gerçekte tek bir aktör tarafından gerçekleştirilip gerçekleştirilemeyeceğidir. Ayrıca faydaların artırılıp artırılamayacağı sorusu bu noktada önem kazanmaktadır. Maliyetler, ortak faaliyetler yoluyla ilgili malların sağlanmasında etkinliğin ve verimliliğin artırılmasıyla azaltılabilir. Bu nedenle, farklı türde malların kimin tarafından üretildiği, kimin faydalandığ iyi bir şekilde anlaşılmalıdır. Bu bir içerik sorunundan çok, küresel etkiye sahip hedeflere ulaşmak için ne tür bir işbirliğine ihtiyaç duyulduğuna dair metodolojik bir sorundur. Bu nedenle aynı anda çok sayıda özelliği bünyesinde barındırmalıdır (Schomaker, 2017: 122).

Belirli hastalıkların ekonomik kriterleri yerine getirmemesine rağmen, hastalık kontrolünün küresel bir kamu yararı olarak kabul edilmesi ve bu nedenle KKM alanına dâhil edilmesi çeşitli yaklaşımlarla açıklanabilir. Bu yaklaşımlar (Schomaker, 2017: 134):

- Kalkınma Yaklaşımı: Yoksul ülkeler için genel bir ekonomik gelişme birçok IO'nun ana hedefidir. Bununla birlikte sürdürülebilir bir kalkınma için halk sağlığı ve hastalık kontrolü oldukça önemli faktörlerdir. Ancak yine de bu ülkeler, IO kendi gelişim hedeflerini gerçekleştirme sorumluluğunu ve maliyetlerini üstlenmektedir.

- Bürokrasi Teorisi Yaklaşımı: Bürokrasi, kurumun bütçesi ve kapsamı açısından tanımlanan hedefleri en üst düzeye çıkarmaya çalışır. Bu nedenle bir IO için üye ülkelerden veya özel sektördeki finansal kaynaklardan, ek sorumlulukların üstlenilmesinde güçlü bir teşviğe ihtiyaç vardır.

- Rekabet Yaklaşımı: Son yıllarda, IO'larla, özel kuruluşlar ve sivil toplum kuruluşları arasında bazı işbirlikleri ortaya çıkmıştır. Bunlar hayırsever kuruluşlar olarak da ayrıca örgütlenmektedir. Ürünleri sağlamak için belirli bir gerekçelendirme yapıldığı KKM'lar olarak etiketlemek, kalkınma yardımı için IO'ların "pazar payını" arttırabilir. 
Bu görev için doğal adaylar, tanım gereği birden fazla devleti içeren ve sadece tek ülkeyi değil ülke gruplarını, bölgeleri veya bir bütün olarak dünyayı etkileyen zorlukları hedefleyen IO'lar olabilir. Ancak, hem bütçe kısıtlamalarından hem de gerçek bir yürütme gücüne sahip olmamalarından dolayı IO'ların kapsamı genellikle sınırlıdır. Birçok durumda, özel teşebbüsler ve ulusal idareler arasındaki ortaklıklara benzer şekilde, özel firmalar veya kuruluşlar da yer almaktadır. İşbirlikleri sadece finansal kaynakları değil, aynı zamanda ortaklığa özgü bilgi ve becerileri de sağlayarak, genel hedeflere ulaşma olasılığını arttırırlar (Schomaker, 2017: 123).

Küresel sağlık sorunları için tartışılması gereken bazı senaryolar vardır. Bunlardan ilki; sınır ötesi bir hastalığın yayılmasını engellemeye yönelik tüm tedbirlerin, o hastalıkla en az mücadele eden ülkedeki kadar önemli olduğunu göstermektir. Yalnızca bir ülkede bile zayıf bir hastalık kontrolü varsa ve karantina önlemleri veya ilaçların yeterli bir şekilde dağıtılması garanti edilemiyorsa, tüm ülkeler bu başarısızlık için bedel ödemek zorunda kalacaklardır. Diğer ülkelerdeki sağlığı artırıcı önlemler bile toplam faydaya önemli ölçüde katkıda bulunmayacaktır. Bu senaryo, bir tedavi veya bağışıklamanın (henüz) eksik olduğu ve KKM'nin esas olarak önleyici tedbirler ile sağlanmasının gerektiği tüm sağlık sorunlarına uygulanabilir. İkinci senaryo, kamu yararı sağlama konusundaki genel başarının, en büyük bireysel tedarik düzeyinin kalitesine bağlı veya eşit olduğu gerçeğiyle karakterize edilir. Böylece kaynakların bir araya getirilmesi verimli bir hal alır. Bir tedavi arayışında, en büyük çabayı harcayan araştırma ekibinin başarması büyük olasılıktır. Tedavi bulunduğunda veya bir keşif yapıldıktan sonra, ek çabalar gereksiz hale gelecektir. Potansiyel tedarikçilerin başarı olasılığı eşit olsa bile, birden fazla sağlayıcı mantıklı olabilir (Schomaker, 2017: 130). Her iki senaryo da ulusal ve bölgesel düzeydeki kamu mallarının yanı sıra KKM'lar için de geçerlidir.

KKM konsepti, özellikle küreselleşme bağlamında sağlık risklerinin ulusal sınırları aştığını göstererek; küresel toplumu, hastalıkların yok edilmesi, sağlığın geliştirilmesi ve korunması için çabaları desteklemeye teşvik etmektedir. KKM kavramı, Birleşmiş Milletler Kalkınma Programı (UNDP) tarafından desteklenen (Woodward vd., 2001) gündemin bir parçasıdır ve eylem için bir çerçeve, normatif bir öncül ve "halk sağlığının kavramsallaştırılmasında" paradigmatik bir değişime hizmet etmiştir (Brown, 2008).

\section{Küresel Sağlık Politikası Aktörleri}

Bu kısımda sağlık yönetiminde rol alan devlet dışı kurumlar ele alınacaktır. Belirtmemiz gerekir ki; uluslararası sağlık politikası işleyişi hakkında ampirik veri eksikliği bulunmaktadır. Aynı zamanda çoğu araştırma, büyük organizasyonlara odaklandığından, teorik araştırmaların odağı daralmaktadır. Uluslararası ve ulusal sağlık politikalarının oluşturulmasında IO'lar (Uluslararası Organizasyonlar), KKÖSİ'ler (Küresel Kamu Özel Sektör İşbirlikleri) ve STK'ların (Sivil Toplum Kuruluşları) konumu net değildir ve bu kuruluşların başarılarını ve başarısızlıklarını değerlendirmek için genel kabul görmüş ortak ölçütlerde ve analitik çerçevede eksiklikler söz konusudur (Okma vd., 2015).

\section{Uluslararası Organizasyonlar (IO)}

Küresel amaçlara sahip her kurum, belirli amaç ve hedeflerden bağımsız olarak, uluslararası bir kuruluş olarak tanımlanabilir. Örneğin; belli bir hastalığın ortadan kaldırılması gibi sadece tek bir hedefe odaklanmış ancak dünya çapında etkin olmayı amaçlamış bir kuruluş ya da 
benzer şekilde yoksulluğun azaltılması gibi genel bir amaçla bir dizi eylem için bir yetki alanına sahip olan bir organizasyon IO olarak kabul edilebilir. Buna göre, IO'ların büyüklüğü, organizasyonel yapısı ve etkisi önemli ölçüde farklılık gösterebilir, bu da sunulan hizmetleri etkileyebilir. Bununla birlikte, IO'lardaki geleneksel küresel işbirliği biçimlerinin çoğunda birçok özellik tanımlanabilir ve bu nedenle IO'lar kurucu mekanizmalar olarak görülebilir (bkz. Buse ve Walt 2000a). IO'ların görevleriyle ilgili şu iki ayrımdan söz edilebilir:

- Temsil ve Örgütsel Görevler: Neredeyse tüm IO'larda, tek tek ulusal devletler ile uluslararası düzeydeki temsilleri arasında hiyerarşik, bürokratik bir ilişki olan dikey temsil biçimi vardır. Çoğu IO'nun organizasyonel yapısı, “üyelerin” IO'nun kurallarını oluşturmasına ve doğrudan bir yönetici seçmesine izin verir. Bu nedenle, sadece ulusal devlet değil, aynı zamanda vatandaşların da karar almada bir dereceye kadar temsil edildiği bu IO'lar temel demokratik bir yaklaşım olarak görülebilir. Buna karşılık, belirli bir amaç için lobi grupları olarak hareket eden birçok kâr amacı gütmeyen kuruluş, bu tür bir temsil ve meşruiyete sahip değildir ve bu nedenle dışlanmışlardır.

- Finansman: Genel olarak, IO'lar kendi ulusal üyelerinden gelen katkılarla finanse edilmektedir. Bu nedenle, organizasyon ilgili ülkenin GSYİH'sine dayalı olarak, belirli bir ödeme planı ile hükümetler tarafından finanse edilmektedir. Ek olarak, üçüncü taraflardan yapılan bağışlar, bu kuruluşlarda kalıcı bir ortaklık teşkil etmeden veya IO'nun yapısı ve politikaları üzerinde herhangi bir etki oluşturmadan, bir finansman kaynağ1 olabilir. Yine de, düzenli ödeme ulusal devletlerden geldiği için konu, ilgili ülkelerin vatandaşlarının vergi ödemeleri ile ilgilidir.

\section{a. Dünya Sağlık Örgütü (WHO)}

1948'de, UN'nin üye ülkeleri WHO'yu oluşturmak için bir araya gelmiş; uluslararası toplum, "uluslararası sağlık çalışmasında yetkilendirme ve koordinasyonu üstlenme" görevini alan yeni örgütün hedefi olarak "tüm halkların mümkün olan en yüksek sağlik düzeyini kazanımı" olarak belirlemiştir. Görev süresi nedeniyle WHO, önemli bir uluslararası sağlık yetkilisidir (Missoni, 2008).

Gönüllü fonların genel bütçesindeki ağırlıklı payı, WHO'nun özerkliğinin en gözle görülür engeli olmaya devam etmektedir. Bütçe dışı fonlar toplam gelirinin \%50'sinden fazlasını oluşturmaktadır. Bazı yazarlar bütçe dışı fonlamanın, WHO'nun bölgesel yapısının ve organizasyonun farklı yönetim düzeyleri arasındaki ilişkilerin çalışmasını zayıflatabileceğini iddia etmişlerdir. Bu aynı zamanda bu fonların WHO aktiviteleriyle potansiyel müdahalesini azaltmak için doğru yaklaşım olabilir. Ne var ki, sanayileşmiş ülkeler çıkarlarının tehlikede olduğunu hissettiklerinde, katkılarını geri çekme konusunda kuruluşa baskı yapma potansiyeline de sahip olacaklardır (Missoni, 2008).

\section{b. Dünya Bankası (WB)}

Mayıs 2007'de, WB tarafından başlatılan yeni Sağlık, Beslenme ve Nüfus Stratejisi memnuniyetle karşılanmış ve bankanın yönetim kurulu tarafından resmi olarak onaylanan stratejisi, yoksul ülkeleri desteklemede önemli bir adım olarak gösterilmiştir. Sağlık sistemleri, insanlara sunulan sağlık hizmetlerini iyileştirir ve yoksulluğu azaltır. Aslında, bu stratejisi ile Banka, uzun vadeli ülke güdümlü ve ülke liderliğindeki desteğe yeniden odaklanmaktadır. Banka özellikle sağlık sistemindeki konumunu güçlendirme, sağlık finansmanı ve ekonomi 
konularında karşılaştırmalı avantajlarını artırmaya karar vermiştir. İlk adımlar arasında uluslararası yardımın uyumlaştırılması ve ülke düzeyinde "işbirliği" için WHO ve Küresel Fon ile özel anlaşmaların kurulmasını öngören WB, öncelikli hastalık operasyonlarına yönelik sistemin yaygınlaştırılmasının gereğini kabul etmektedir. Hastalık kontrolünün teknik yönleri, insan kaynakları eğitimi ve hizmet sağlayıcılığı ile diğer kuruluşlardan (WHO, UNICEF, UNFPA ${ }^{4}$ ) ayrılan Banka, sağlık sistemi politikalarının geliştirilmesi için lider küresel kuruluş konumundadır. Yeni stratejinin uygulanmasına yönelik tecrübe ne olursa olsun, uluslararası harcamaların sağlık üzerindeki payının \% 10'undan fazlası ile WB, şüphesiz küresel sağlık yönetiminin merkezi bir oyuncusu olmaya devam etmektedir (Missoni, 2008).

\section{c. Sağlık 8 (H8)}

Sağlıkta yeni bir küresel aktör grubu artık "H8" olarak tanımlanmaktadır. Grupta WHO ve WB'ın yanı sıra Gates Vakfı, GAVI İttifakı, Küresel Fon, UNAIDS, UNFPA ve UNICEF H8' de yer almaktadır. Bunlar arasında Gates Vakfı dışındakilerin tamamı uluslararası kurumlar ya da farklı konular arasında ittifaklardan oluşan çok taraflı yapılardır (Missoni, 2008).

1992'den beri toplam resmi kalkınma yardımlarında düşüşe rağmen, sağlıkta kalkınma yardımı büyük ölçüde büyümeye devam etmiştir. Çok taraflı kurumlar sağlığa toplam kalkınma yardımının üçte birini sağlamaktadır ve bu yardımın \% 80'i Uluslararası Kalkınma Derneği'nden gelmektedir. Yeni bir finansman kaynağı olarak, Bill ve Melinda Gates Vakfi'nın (BMGF) Küresel Sağlık programı, sadece boyut bakımından değil, aynı zamanda sağlık politikasının belirlenmesinde de önemli bir yer tutmaktadır (Ollila, 2005).

Sağlık için kalkınma yardımı büyük ölçüde bulaşıcı hastalıklarla mücadeleye yönlendirilmektedir. ABD Uluslararası Kalkınma Ajansı (USAID), otuz yılı aşkın süredir aile planlaması dâhil olmak üzere nüfus programlarını finanse ederken, sağlık konularına verdiği önem daha yenidir. 2002 yılında USAID'in sağladığ finansman nüfusu, sağlık ve beslenme fonu, HIV/AIDS, aile planlaması/üreme sağlığı, anne/çocuk sağlığı ve bulaşıcı hastalıkları kapsamıştır. BMGF ise küresel sağlık politikası yapımı için GAVI (Aşı ve Bağışıklık İçin Küresel İttifak) gibi yeni yapıların kurulması için stratejik fon sağlamıştır. Küresel Sağlık programı, tekrarlayan maliyetler ya da kronik koşullar finanse edilmemekle birlikte, teknolojilerin geliştirilmesi ve uygulanmasına vurgu yaparak, bulaşıcı hastalıkların önlenmesi, aşı araştırma ve geliştirme, üreme ve çocuk sağlığı üzerine odaklanmaktadır. GAVI, ciddi oranda BMGF finansmanı ile yeni aşıları da hedeflemiştir. Küresel Sağlık girişimi kapsamında BMGF tarafından finanse edilen yeni sağlık teknolojisi araştırmaları ve kalkınma fonları yoluyla sağlık sorunlarının üstesinden gelmek için çaba sarf edilmiştir (Ollila, 2005).

\section{Küresel Kamu Özel Sektör İşbirlikleri (KKÖSİ)}

Pareto optimalitesinden sapmalar ve sağlık hizmetlerinin temel özellikleri gibi argümanlarla, sağlık hizmetinin kamu kesimi tarafından sunulmasının gerekliliğini savunan görüşlere karşın (Ertürk Atabey, 2012; 22; Gediz Oral, 2016b: 141: Stiglitz, 1994; 350) kamunun kaynak ihtiyac1, etkinlik, verimlilik ve kalite taleplerine cevap verebilmek için, alternatif hizmet sunum arayışları KÖSİlerin süreçteki rolünü giderek yaygınlaştırmıştır (Gediz Oral, 2016b: 187).

KKÖSI'ler, devlet ve devlet dışı aktörleri, ürün geliştirme, tanıtım, kalite sertifikasyonu, teknik destek, yardım hizmetleri sunmak ve finansman gibi amaçlarla sağlık, eğitim ve teknoloji gibi belirli işlevleri yerine getirmek için bir araya getiren gönüllü ve işbirlikçi ilişkilerdir (Brown, 2008; Missoni ve Pacileo, 2015: 202-203). KKÖSİlerin ekonomik açıdan kabul edilebilir 
olabilmeleri için; küresel kamusal bir malın varlığı, sektöre özgü teknik becerilere ihtiyaç duyma, uluslararası kuruluşlar veya üye devletler tarafından tek başına sağlanamayan finansman ihtiyacı gereken önkoşullardır (Rangan vd., 2006: 738).

$\mathrm{Bu}$ hususları takiben, sağlık konularıyla ilgili KKÖSİleri sınıflandırmanın birkaç yolu vardır (Schomaker, 2017: 130):

- Yasal statüye göre: Yasal olarak bağımsız olanlar kuruluşlar veya sözleşme anlaşmaları, geleneksel bir IO, özel bir şirket veya geleneksel kâr amacı gütmeyen bir organizasyonda (lobi grupları, kiliseler) barındırılan işbirlikleridir.

- Hastalık odağına göre: HIV/AIDS gibi belirgin hastalıklara, ihmal edilmiş hastalıklara veya daha genel olarak sadece bir hastalığa odaklanmalarına göre KKÖSİler farklı siniflandırılabilirler.

- Sektör odağına göre: KKÖSİler, Ar-Ge odaklı, şeffaf mali destek veya politika uygulaması için teknik yardım ve hizmet odaklı, küresel veya ulusal düzeyde lobi faaliyetlerine odaklı olarak da sinıflandırılabilirler.

1990'ların sonunda, kamu ve özel kuruluşlar arasında bir reform çağrısı yapılmıştır. UN Genel Sekreteri Kofi Annan, Birleşmiş Milletler bünyesinde kurumsal reform yapmış ve ekonomik, sosyal ve ekolojik sektörleri entegre etme idealleri üzerine hareket etmeye çalışmıştır (Buse ve Walt, 2000a). Annan, Uluslararası Ticaret Odası'na (ICC), UN kurumları ve özel sektör arasında küresel bir işbirliği aracılığıyla daha fazla ortaklığa teşvik etmek için başvurmuştur. ICC, özel sektörün kr elde etme güdüsünü dikkate aldığı sürece, prensipte mutabakata varmıştır (Buse ve Walt 2000a). Girişim, BM Küresel İlkeler Sözleşmesi'nin lansmanı ile Temmuz 2000'de gerçekleşmiştir. Özel sektöre, sosyal ve çevresel olarak sorumlu bir şekilde hareket etmek için çağrıda bulunulan bu işbirliği, kamu ve özel sektör aktörlerinin küresel sürdürülebilir kalkınma amacıyla birlikte çalışabilmeleri için bir politika çerçevesi sunmuş ve on işletme ilkesini ${ }^{5}$ sağlamıştır (Johnson, 2017: 180).

Değişen senaryoya göre, KKÖSİler, sağlık hizmetlerinin bir takım sağlık sorunları için uygulanmasını iyileştirmek için yeni bir yaklaşım olarak ortaya çıkmıştır. 1990'ların sonlarında birçok KKÖSİ kurulmuş, ancak çoğu HIV/AIDS, tüberküloz ve sıtma gibi belirli hastalıklara odaklanmıştır. KKÖSİlere olan istek dikkate alınmaksızın, bu bağlamdaki başarıları karışık görünmektedir ve etkinliğini değerlendirmek için az sayıda veri bulunmaktadır. Gerçek durum kamu yararının azaltılması ve uluslararası yardımın ileri derecede özelleştirilmesi iken; KKÖSİ modeli "kamunun kaynak sıkıntısını çözmek" amacı öne sürülerek her zirvede çeşitli ve dramatik dünya sorunlarına cevap olarak defalarca önerilmiştir. Sağlıkla ilgili KKÖSİ'lerin sayıları hızla artarak 100'ü aşmıştır. Ancak bu girişimler hem ulusal hem de küresel düzeyde sağlık yönetişimi açısından ve faydalanıcı ülkelerde sağlık hizmetlerinin sağlanmasıyla ilgili ağır sonuçlar doğurmuş, sağlık için yinelenen müdahaleler ve küresel eylemin daha fazla parçalanmasıyla sonuçlanmıştır. KKÖSI'lerin çeşitli hastalık ve sağlık sorunlarını çözmesi nedeniyle uygulanması açıkça desteklenmiştir. Örneğin; başından beri Aşılar ve Bağışıklıklar Küresel İttifakının (GAVI) kuruluşu güçlü bir şekilde desteklenmiştir. Bu KKÖSİ modeli daha sonra Küresel Fon ve HIV/AIDS, Sıtma ve Tüberküloz (GFATM) ile mücadele için referans olarak kabul edilmiştir (Missoni, 2008). 
Bütçe dişı fonlara olan artan bağımlılı̆̆ı sayesinde, WHO'yu etkileyen "bağışçı" ülkelerin ağırlığı artmakta ve bu ülkelerin önemli bir kısmı, KKÖSİ'lerin yönetimine ve açıkça diğer UN kurumlarının yönetimine katılmaktadırlar. Bununla birlikte, daha az sayıda bağışçı ülke, küresel sağlık yönetişim mimarisini değiştirmede liderlik rolünü üstlenmiş görünmektedir. Sonuç olarak, hem KKÖSI'ye yönelik iki taraflı destekleri hem de giderek daha ilgili uluslararası gruplaşmaların kolektif eylemleri yoluyla daha etkili bir rol edinmektedir. Bunlardan en önemlisi G8' dir (Missoni, 2008).

G8'in kolektif bir organ olarak küresel sağlık ajandası üzerindeki etkisi, 2000 yılında, Japonya'nın liderliğinde önemli bir itici güç kazanmış ve Genova Zirvesi'nde HIV/AIDS, Tüberküloz ve Sıtma ile Mücadele Küresel Fonu'nun başlatılmasıyla önemli ölçüde artmıştır. GFATM'in başlatılmasından bir süre önce bu tür bir inisiyatifin uyumsuzluğu konusunda anlaşmaya varılmış olan G8 Sağlık uzmanları da dâhil olmak üzere, ilave bir küresel inisiyatife duyulan ihtiyaç tartışılmaktaydı. Yeni bir inisiyatif için bir anlaşma olmadığ 1 bildirilse de, birçok üye ülkenin eleştirileri, GFATM'nin ABD veya WB tarafından idare edilmesine karşı yönelmiştir. Bazı yazarlar, KKÖSİ'nin taraftarlarının bir amacının da "politika oluşturmada UN sisteminin rolünü zayıflatmak" olduğunu iddia etmiştir. Ancak politik düzeyde önceden belirlenmiş olan bir gündem, nihayetinde Genova'daki G8 toplantısında Küresel Fon'un başlatılmasına yol açmıştır. Bunu takip eden yıllarda çok sayıda özel ek taahhütler ardı ardına gelmiştir. Bunların arasında, çocuk felcini ortadan kaldırmaya ilişkin taahhütler verilmesi, uygun fiyata ilaçlar dâhil olmak üzere sağlık hizmetlerine daha iyi erişim sağlanması, gelişmekte olan ülkeleri etkileyen hastalıkların araştırılması, SARS gibi yeni salgın hastalıklara karşı uluslararası işbirliğinin sağlanması, HIV aşısı geliştirilmesini hızlandırmak için Küresel HIV Aşı Girişiminin kurulması, sağlık sistemlerinin güçlendirilmesi (tedarik zinciri yönetimi ve raporlaması, sağlık çalışanlarının eğitimi dâhil), HIV, tüberküloz, sıtma ve diğer hastalıklara yönelik aşı ve ilaçlar için yenilikçi klinik araştırma programları ve diğer yenilikçi mekanizmalarının araştırma-geliştirme çalışmaları olarak sayılabilir (Missoni, 2008).

GFATM'ye "tam destek" tekrar tekrar yenilenmiş, ancak sadece St Petersburg Zirvesi'nde (2006) G8, üç salgın HIV/AIDS, tüberküloz ve sıtma ile mücadele çalışmalarını düzenli olarak gözden geçirmeyi kabul etmiştir. İzleme çalışması ilk kez Heligendamm G8 Zirvesi'ne göre gerçekleştirilmiş ve Ekim 2007'de bir rapor yayınlanmıştır. 2008' de Toyako'da G8, bu durumu izlemek için düzenli bir izleme mekanizması kurmaya karar vermiş, taahhütlerini yerine getirme konusunda ilerleme kaydedilmiştir. G8 zirve gündeminde sağlık konularının artan bir şekilde dâhil edilmesi, girişimlerin başlatılması ve fonların artırılması ile grup, ister iyi ister kötü olsun, yine de tartışmaların konusu olan dünya sağlık yönetiminde giderek artan bir rol oynamaktadır (Missoni, 2008).

UNDP gündeminde, KKM kavramı küresel sağlığın sonuçlarının iyileştirilmesi, aynı zamanda kolektif eylem yoluyla ara ürün ve hizmetlerin sağlanması amacını taşımaktadır. Hastalık gözetimi, hastalık kontrolü, hastalıkların ortadan kaldırılması, hastalık tedavisi gibi ara malları sağlamada KKÖsİler önemli bir rol üstlenmişlerdir. Bununla birlikte, KKÖSİ aracılığıyla ara malların tedarik edilmesi, küresel sağlık sonuçlarında ve sağlıkta küresel işbirliğinin elde edilmesinde çeşitli olumsuz dışsallıklara sahiptir (Brown, 2008).

\section{Sivil Toplum Kuruluşları (STK)}

STK'lar yeni bir olgu değildir. Avrupa misyoner toplulukları 16. yüzyılın sonlarından bu yana din ihracını eğitim ve sağlık desteğiyle birleştirmiştir. Batı Avrupa'daki işçi hareketleri, dinsel 
ve diğer hayır kurumu tarafından desteklenen dernekler, 19. yüzyılın sonlarından bu yana sınırların ötesinde faal duruma geçmiştir. Bazı büyük STK'lar, örneğin Rockefeller (1911) ve Ford Vakıfları (1936) gibi uzun yıllardır var olmuşlardır. Ancak, sağlık odaklı mevcut STK'ların çoğunluğu 20. yüzyılın son otuz yıllında yaratılmıştır. STK faaliyetleri, sanat ve eğitim (özellikle Amerikan STK'ları için önemlidir), çevre ve sosyal kaygı gibi geniş bir yelpazeye yayılmaktadır (Okma vd., 2015).

STK'lar hükümetler ve piyasalar arasındaki boşluğu doldurmakta ve hükümetler veya uluslararası kuruluşlar tarafından sunulmayan hizmetleri sunmaya yönelmektedirler. STK gelirleri, gönüllü katkılardan ve (bazen önemli miktarda) devlet sübvansiyonundan oluşur. STK'ların popülaritesi, dolandırıcılık ve istismar üzerine medya haberleri ve endişelerin ardından son on yılda bir miktar gerilemiştir. STK'ların şeffaflığını ve hesap verebilirliğini artırmak için baskı uygulanmaktadır. Büyük STK'ların IO'lerden farklı olmak için, kökten bir yön değişikliğine ihtiyaç duydukları ve hizmete erişemeyen nüfusa odaklanmaları gerektiği savunulmaktadır (Okma vd., 2015).

\section{Bill \& Melinda Gates Vakfı (BMGF)}

Küresel Sağlık Programı için 1,97 milyar dolarlık bir harcama ile 2007'de Bill \& Melinda Gates Vakfı, OECD ülkelerinin sağlı̆̆ı için Uluslararası Kalkınma Derneği'nin taahhütlerini ve ABD'yi geride bırakmıştır (Missoni, 2008). Buna ek olarak, bağışlarla yıllık gelirlerinin yaklaşık 3.474 milyar dolara çıkacağı ve şüphesiz Gates Vakfi'nın küresel sağlığın en önemli aktörlerinden biri olarak sınıflandırılacağı öngörülmektedir (Missoni, 2008).

Çeşitli küresel sağlık inisiyatifleri, araştırma enstitüleri ve STK'lar aracılığıyla IO'lara fonlarını kanalize eden Gates Vakfı, bir dizi yönetim organında yer almakta ve böylece karar verme sürecine etki etmektedir. Gates Vakfı, 2000 yılında başlatılan KKÖsİ modeli olan GAVI ittifakının kurucusu ve büyük ortağıdır (Missoni, 2008). Bill \& Melinda Gates Vakfı'nın 750 milyon dolarlık ilk beş yıllık katkısıyla Ocak 2000'de kurulan GAVI, gelişmekte olan ülkelerde aşılama kapsamını ve kalitesini artırmaya odaklanmış ve ortakları arasında UN kurumları (UNICEF, WHO, WB), sivil toplum kuruluşları (Uluslararası Pediatri Derneği), halk sağlığı enstitüleri (Johns Hopkins Bloomberg Kamu Sağlığı Okulu), bağışçı ve uygulayıcı ülke hükümetleri, Bill \& Melinda Gates Vakfı, diğer özel hayırseverler, aşı sanayi temsilcileri ve finans topluluğunu içermektedir (Missoni, 2008).

\section{Sinır Tanımayan Doktorlar (Médecins Sans Frontières -MSF)}

Savaştan etkilenmiş ve/veya gelişmekte olan ülkelerdeki endemik hastalıklarla mücadele eden, insani yardım amaçlı bir organizasyondur. MSF 20 Aralık 1971'de Dr. Kouchner öncülüğ̈̈nde iki bağımsız doktor ve gazeteci grubu tarafından Paris'te kurulan, desteğini özel girişimcilerden sağlayan bağımsız bir sivil toplum kuruluşudur (Gediz Oral, 2014). MSF 32.000'den fazla sağlık personeli ile dünya çapında ofisleri olan 24 ulusal MSF birliği bulunmaktadır. MSF'nin dünya çapındaki bağışlarla 5 milyon dolar civarında geliri bulunmaktadır. MSF'nin ana hedefi, insan ya da doğa kaynaklı felaket mağdurlarına acil tıbbi bakım sağlamak ve ekonomik kriz ya da diğer nedenlerle doğan istikrarsız durumlara müdahale etmektir. MSF, düşük gelirli ülkelerdeki sağlık gelişimini esas hedef olarak görmez, ancak tıbbi projelere katkıda bulunur. MSF, kendisini, sokak çocukları, seks işçileri ve göçmenler gibi yetersiz ve marjinalize olmuş nüfus için, farklı uluslararası platformlarda küresel ve ulusal sağlık politikalarını etkilemek konusunda da bir ses olarak görmektedir. Uluslararası sağlı politikası gündemine ihmal edilen hastalıkları (sıtma, HIV/AIDS, 
tüberküloz ve zihinsel sağlık) getirmiştir. Kronik hastalıkların tedavisinde ise aktif hale gelmiştir. Son olarak, MSF, aşıların, örneğin grip aşısı geliştirilmesi ve dağıtımını desteklemektedir. 2010 yılında MSF, rutin çocuk felci aşılaması ve düşük aşı fiyatları için bir kampanya başlatmıştır. MSF'nin personeli zaman zaman çok zor koşullarda çalışmaktadır. Hatta 2013'te, MSF personeli tehdit edildiği, kaçırıldığı ve öldürüldüğü için Somali'den çekilmiştir.

Bununla birlikte, örgüt, "yüksek standartlar" yaratma konusunda eleştirilere maruz kalmaktadır. Çünkü yüksek standartlar, maliyetleri de yükselttiğinden yerel örgütler veya hükümetler daha sonra bu maliyetlerin üstesinden gelemediklerinde projenin çökmesine neden olmaktadır. Hesap verebilirlik açısından, MSF finansal paydaşlarına göre daha fazla dikkat etme eğilimindedir (Okma vd., 2015).

\section{Küresel Sağlık Yönetişimi}

Küresel sağlık politikasındaki başlıca aktörler değişmiş, politika alanına yeni aktörler girmiş ve eskileri güç kaybetmiştir. Genel değişim, küresel ulus temelli sağlık politikası oluşturma yapılarından, özel sektör aktörlerine vurgu yapan daha fazla çeşitliliğe doğru gerçekleşmiştir. 1980'lerde ve 1990'larda, UN kurumlarından finansal kurumlara doğru küresel sağlık politikası yapımında bir değişim olmuştur. Bu değişim, özel aktörlerin sağlık politikasına dâhil edilmesine gösterilen ilginin artması anlamına gelmektedir. 20. Yüzyılın sonlarına doğru $\mathrm{UN}$, iş dünyasıyla giderek daha fazla işbirliği yapmıştır. Bu gelişme kısmen, OECD ülkelerinin özellikle UN'e olan kalkınma yardımlarının azalmasından kısmen de genel politika yapımında güç kazanmış olan ve kurumsal sektörle işbirliğini arttırmadığı takdirde marjinalleşmesinden korkulan UN'den duyulan endişeden kaynaklanmaktadır (Ollila, 2005).

UN, sivil toplumun küresel politika yapımında önemli bir aktörler topluluğu olarak tanınmasına katkı sağlamıştır. Sağlık meseleleriyle ilgili olarak, sivil toplumun kâr amacı gütmeyen kuruluşları, özellikle temel ilaçlar, anne sütü yerine geçen gıdalarla ilgili tartışmalarda çok daha önemli bir rol oynamışlardır. Halk sağlı̆̆ı STK'ları, örneğin, ilaç politikalarını şekillendirmede ve HIV ile enfekte kişilerin ihtiyaçlarını ve haklarını vurgulamada önemli olmuştur (Ollila, 2005:1).

Yeni ortaklık biçimlerinin ortaya çıkışını açıklamaya yönelik ortak varsayım; dünyanın geldiği noktada durumun IO'ların sınırlarını aşmış olduğudur. Çünkü küresel ve ulus ötesi kamu mallarında bir artış olmuştur ki bu da ek kaynak ve becerilere olan ihtiyacı artırmaktadır. Yeni ihtiyaçların daha karmaşık olması, küreselleşmeyle birlikte dünya ekonomilerinin ve toplumlarının artan entegrasyonu, yeni teknolojilere olan gereksinimin artması gibi sebeplerle, bu ihtiyaçların tek başına kamu sektörü ve/veya IO'larca sağlanması mümkün değildir (Schomaker, 2017: 125) .

\section{Küresel Sağlık Yönetiminde Kamu-Özel Sektör Rollerinde Kaymalar}

1970'lerin sonuna kadar, UN veya uluslararası kalkınma sisteminde özel sektör ve kamu sektörleri arasında çok az işbirliği yaşanmış ve ilişkiler her iki tarafa da az güven vermiştir. Var olan ortaklıklar, büyük ölçüde bağışçı kurumlar ve alıcı ülke hükümetleri arasındaki kamu sektörü ilişkileri ile sınırlı kalmıştır. UN, kâr amacı gütmeyen sivil toplum kuruluşlarıyla istişare için uygun düzenlemelere izin vermesine rağmen, UN kurumları ve 
STK'lar arasında neredeyse hiç ortaklık oluşturmamıştır. STK'lar genellikle zorlayıcı "baskı grupları" olarak tanımlanmıştır (Buse ve Walt, 2000b).

1980'lerin başında, neo-liberal ideolojiler kamu politikasını ve tutumlarını etkiledikçe ilişkiler değişmeye başlamıştır. Etkili IO'lar, özel sektör için daha büyük bir rol üstlenmiş ve onları desteklemiştir. Bağışçı ülkeler, proje çalışmalarında ortak çalışanlar için devletin ötesinde daha geniş ilişkiler kurmaya başlamıştır. Örneğin, WB 1981'de STK'lar hakkındaki ilk “Operasyonel Politika Notu"nu kabul etmiş ve 1982'de bir STK-Dünya Bankası komitesi kurulmuştur. Bağış yapan kuruluşlar, STK'lar aracılığıyla fon artırımına yönlenmiş ve 1998 yılına kadar toplam yurt dışı kalkınma yardımlarının \% 15'i STK'lar aracılığıyla sağlanmıştır. UNICEF ve WHO gibi UN kurumları ile Bebek Maması Eylem Ağı gibi sivil toplum kuruluşları arasındaki ortak eylem, Uluslararası Meme Kanseri Değiştirme Kanunu gibi adımlar temel ilaç politikalarına karşı endüstriye meydan okumuştur (Barr, 2007; Walt, 1998; Missoni, 2008). Bu karşılaşmaların bir kısmı başlangıçta çatışmalardan kurtulamamış ve güvensizlikle karakterize edilmişken, 1980'lerin sonunda bu polemikler, STK'ları, sanayiyi ve kamu sektörünü birbirine bağlayacak araştırmalara yol açmıştır (Buse ve Walt, 2000b).

Özellikle kâr amacı gütmeyen kuruluşlar ve kamu sektörü arasındaki ittifak, sağlık için uluslararası işbirliği bağlamındaki bazı değişikliklerin sonucudur. Birincisi, 1990'larda yaşanan ideolojik kayma ile "tıpta saf kamu hizmeti çağının bittiği" iddia edilirken, serbest piyasa savunucuları özellikle sağlık alanında çoğu zaman piyasaların verimsiz olması ve eşitliğin sağlanmasını zorlaştırması gibi sebeplerle kamu sektörünün devam eden rolünü fazla görerek, pozisyonlarını değiştirmişlerdir. Bu nedenle, saf bir serbest piyasa durumu yaratmaktansa, tüm seriyi bir araya getiren, tüm tarafları koruyan tedbirlerin alındığı bir modifiye edilmiş piyasa mekanizması yaratılmaya çalışılmıştır. Bu ideolojik değişim bağlamında, UN'nin sanayi ortaklığının faydaları vurgulanmış, UN'i "yeniden meşrulaştırmak" hedeflenmiş ve bu sayede de UN'nin küresel politika yapımında daha merkezi bir konuma kavuşmasının sağlanabileceği düşünülmüştür (Buse ve Walt, 2000, Buse ve Harmer, 2007; Missoni, 2008). UN olarak biçimlendirilmiş IO'lara yapılan atıfın temel sebebi, UN çerçevesinin, küresel bir yaklaşımla IO'lar için örnek teşkil etmesi değil, ekonomik gelişmeyi teşvik etmenin UN genel amacı olmasıdır. Dahası UN, dünya çapındaki özel sektörle yapılan ortaklık anlaşmalarının çoğunu kapsamaktadır (Schomaker, 2017: 125).

Küresel Sağlık Yönetişimi'nin mimarisini tanımlamak ve şekillendirmek amacıyla, “liderlik ve otorite" mesafesine göre bakıldığında, merkezi dairede WHO, WB ve ABD yer almaktadır (Missoni, 2008).

\section{Küresel Sağlık Yönetişiminde Koordinasyon Arayışı}

Küreselleşme, küresel hastalıkları ve sağlık hizmetleri yükünü artan bir oranda yoksul ülkelere yüklemekte ve böylece sağlık sektöründe daha fazla eşitsizliğe neden olmaktadır. Gelişmekte olan ülkelerin bulaşıcı ve bulaşıcı olmayan hastalıkların artmasıyla çift taraflı bir yük yaşaması beklenmektedir. Bu eğilimler, küreselleşen dünyada ulusal sağlık yönetişiminin sınırlarını ortaya çıkarmıştır. Hükümetler, anlaşmalar, küresel kamu politikası ağları, KKÖSI'ler ve diğer düzenlemeler gibi yeni işbirliği biçimlerine gitgide daha fazla sıcak bakmaktadır. Sağlığın teşviki ve geliştirilmesi, yönetimden yönetişim ${ }^{6}$ yöntemlerine geçiş ile giderek daha fazla karakterizedir (Missoni, 2008).

Son yıllarda devlet dişı aktörlerin sağlık yönetimindeki sayısında ve nüfuzunda bir artış olmuştur (Besley ve Ghatak, 2007; Dodgson vd., 2002). Sivil toplum kuruluşları, özel şirketler, 
danışmanlar, araştırma enstitüleri ve dinsel hareketler; politika oluşturma, politika uygulama, hizmet ve ürün sağlama, araştırma ve geliştirme alanlarında rol alarak sağlık yönetimine katılmaktadır. Dahası, devletin geleneksel sağlık yönetişim işlevlerinin çoğu devlet dışı aktörlere (örneğin, sağlık hizmetlerine ait mülkiyet veya sorumluluğun özel sektöre ya da sivil toplum kuruluşlarına devredilmesi) ya da devlet ve devlet dişı aktörlerin birleşimlerini içeren "kamu yönetiminin özel sektörle büyüyen işbirliklerine-kamu özel sektör işbirlikleri (KÖSI)" dönüşmektedir. Bu dönüşüm literatürde "yönetişimin melezlenmesi" olarak adlandırmaktadır (Brown, 2008; Dodgson vd., 2002; Missoni, 2008).

Küresel sağlık yönetiminin merkezi oldukça kalabalık görünmekte ve koordinasyona ihtiyaç duyulmaktadır. Eylül 2007'de, İngiltere Başbakanı Gordon Brown sağlıkla ilgili Binyıl Kalkınma Hedefleri'ne ulaşmak için acilen bir sadeleşmeye gidilmesi gerektiğini ilan etmiş ve mevcut durumdaki hiper-parçalanmış ortama yol açan çok sayıda tekil inisiyatifin başarısızlığını örtük olarak tanıyan yeni bir "Uluslararası Sağlık Ortaklığı"nın (IHP) başlatılmasına öncülük etmiştir. IHP, yedi hükümet (Kanada, Fransa, Almanya, İtalya, Norveç, Portekiz, Hollanda) ve on bir çoktaraflı ortak (Afrika Kalkınma Bankası, Bill \& Melinda Gates Vakfı, Avrupa Komisyonu, GAVI, GFATM, UNAIDS, UNICEF, UNFPA WHO, Dünya Bankası, UN Kalkınma Grubu temsilcileri) tarafından imzalanmıştır. İlginç bir şekilde, başta $A B D$, Japonya ve Rusya Federasyonu olmak üzere üç G8 ülkesinin temsilcileri, kurulda yer almamıştır (Missoni, 2008).

IHP, yoksul ülkeler için sağlık yardımını daha iyi hale getirmeyi ve üç şey yaparak ilerlemeyi hızlandırmayı hedeflemektedir: (1) bağışçılar arasında daha iyi bir koordinasyon sağlamak; (11) sağlık sistemlerini bir bütün olarak iyileştirmeye odaklanmak ve (111) sadece bireysel hastalıklar veya meseleleri değil; ülkelerin kendi sağlık planlarını geliştirmek ve desteklemek. Buradaki fikir, donör ülkelerin ve ajansların, yoksul ülkelere uzun vadeli ve daha öngörülebilir bir finansman sağlama yönünde çalışacaklarıdır. Böylece yoksul ülkeler, yeni doktorlar ve hemşireler yetiştirmek için gerekli kaynaklara sahip olacaklar uzun vadeli planlar yapabileceklerdir (Missoni, 2008).

IHP olumlu ve daha önceki uluslararası ortamlarda alınan taahhütler ile uyumludur: Binyıl Bildirgesi kapsamında ulaşılması gereken hedefler ve ana aktörlerin bağlılığı ile ilgili gerçekleştirilen Paris Deklarasyonu, 5 temel prensipte düzenlenmiştir: mülkiyet, uyum/ uyumlaştırma, yönetme, sonuçlar ve karşılıklı hesap verebilirlik. Bununla birlikte, küresel sağlık senaryosunun birbirinden bağımsız çoklu yapısını tek bir çerçevede bir araya getirme çabaları net bir şekilde sonuçlanamamaktadır (Missoni, 2008).

1990'ların başından beri, UN - WHO, UNICEF, UNDPA, UNFPA ve WB dâhilinde sağlık sektörüne ciddi katılımı olan çeşitli oyuncular arasında artan bir görev dağılımı yaşanmaktadır. Gelişmiş ülkeler ve en güçlü ikili bağışçıların çıkarlarına ve vizyonuna daha yakın ve onların etkisi altında, giderek öncü bir rol kazanmıştır. İlgili UN kurumlarına verilen desteğin azalması, verimlilik ve etkililiğine olan güven kaybıyla motive olmuştur. Buna karşılık olarak, pozisyon ve güvenilirliğin yanı sıra yeni gelir kaynaklarına kavuşmayı hedefleyen UN, bu durumu piyasa güçlerine yönlendirmiştir.

Sağlığa katkıda bulunan küresel aktörlerin sayılarının ve ilgilerinin günden güne artması, küresel sağlık yönetiminin kalabalık "merkezi" ne farklı oyuncuların dâhil olmasına neden olmuştur. Küresel normların ve ilkelerin uygun bir çerçevede uygulanması için çıkarlar ve güçlerin uyumunun yanı sıra uygun bir liderlik yapısı da gereklidir. Küresel sağlık sahnesinde 
KKÖSI'lere artan ilgi ve genel olarak şirketlerin politika oluşturma sürecine katılımı, bazı endişeleri gündeme getirmektedir. KKÖSİler, küresel politik gündemde bazı sağlık koşullarının (özellikle bulaşıcı hastalıklar) profilini yükseltmiş ve sonuçta belirli eylemler için ilave kaynakların üretilmesine, yeni ürünlerin geliştirilmesine prosedürlerin, normların ve standartların spesifik hastalıkların kontrolünün geliştirilmesine katkıda bulunmuşlardır. Buna karşın bazı gözlemciler ve yazarlar, KKÖSİlerin halk sağlığından ziyade büyük ölçüde eş güdümlenmemiş ve çoğunlukla yüksek profilli hastalıklara yönelik çabalar için ödeme yaptığını belirtmektedirler. Yine aynı kesim, KKÖSİ'lerin meşruiyetini sorgulamakta ve yönetimsel anlamda herhangi bir seçim olmaması, daha geniş bir nüfusu temsil etmemesi, işbirliği süreçlerinde nispeten zayıf aktörlerin yeterince etkin olmaması yönüyle eleştirmektedir.

KKÖSİ'lerin kimin kime ve ne için sorumlu olduğu konusunda hesap verme sorumluluğunda belirsizlik söz konusudur. Bu durum prosedürleri artırmakta ve politika oluşturma sürecini zorlaştırarak küreselleşmenin etkinliğini baltalamaktadır. Buna ek olarak, kurumlar kendi aralarında da rekabete girmekte ve finansman mekanizmalarını çarpıtmaktadırlar. Ayrıca KKÖSI'ler için bir takım etik kaygılara da vurgu yapılmaktadır. Bunlar arasında, küresel normlar ve ilkeler çerçevesinin yokluğu, bir ortaklık düzenlemesinde hangi küresel halk sağlığı hedeflerinin takip edilebileceğinin belirsizliği, kamu sektörünün misyonu ve örgütsel öncelikleri ile sağlıkta eşitlik ilkesiyle çelişen çağrışımları, sosyal güvenlik ağlarının sağlanmasında kamu sektörünün rolünün azaltılması, bu durumun laissez-faire (bırakınız yapsınlar) tutumuna yol açması, en savunmasız grupların menfaati için önyargılı ve halk sağlığı hedefleri ile özel sektörün uzun vadede ödeme talepleri arasındaki çıkar çatışmaları yer almaktadır (Missoni, 2008).

Küresel sağlık politikaları, iş dünyası ile birlikte gerçekleştirilmekte, böylece endüstriyel politikalar ve ticaret politikaları ile giderek daha uyumlu hale getirilmektedir. Bunun sonucu olarak hem küresel hem de ulusal düzeyde etkili düzenlemeler ve normatif eylemler gerçekleştirilebilmektedir (Ollila, 2005). Ancak; UN ve özellikle WHO, görev ve amaçlarını gözden kaçırmış gibi görünmekte ve şirketlerin kâr güdülerine ve piyasa mantığına meydan okuyan meseleleri ele alamamaktadır. Bu eğilim, az sayıda ülke tarafından tek tek veya toplu olarak, özellikle teşvik edilmiştir ve bu durum en çok G8 ile ilişkili gibi durmaktadır. Sektördeki kurumların ve özel vakıfların katkıları sağlıkla mücadelede ve insanların yaşam koşullarının iyileştirilmesinde büyük bir değere sahip olabilir. Ancak bu amaçla, sadece halk sağlığının yüksek yararı göz önünde bulundurularak seçilen karar ve yaklaşımların dikkate alınması gerekmektedir.

$\mathrm{Bu}$ ilgiyi yansıtacak meşruiyet ve yeterlilik hala $\mathrm{WHO}^{\prime}$ da bulunmaktadır. Küresel inisiyatif için küresel çabayı yönlendirmek ve koordine etme kabiliyetindeki UN kurumunu güçlendirmek küresel toplumun çıkarına olacaktır. Bazı yazarların genel olarak çok taraflı kurumlar için tartıştıkları gibi, WHO liderlerinin ve savunucularının da meşruiyetini yeniden oluşturmaya başlaması gerekmektedir. Ayrıca "şeffaflığın, hesap verebilirliğin ve doğrudan baskının rolünü sınırlayan hükümler gibi demokrasinin belirli yönlerinin, çok taraflı kurumlara nasıl dâhil edilebileceğinin ve gayri meşruiyet suçlamalarına karşı nasıl daha sağlam bir hale getirilebileceğinin" araştırılması gerekmektedir. Küresel sağlık yönetiminin gelecekteki haritasında "herkes için sağlık" açısından, WHO sağlık yönetiminin merkezinde yalnız kalmalı, ancak daha geniş katılımı sağlamak için gözden geçirilmiş iç mekanizmalara sahip olmalıdır (Missoni, 2008). 


\section{Sonuç}

Sağlığın kavramsallaştırılması, küresel sağlık işbirliğinde kritik öneme sahiptir. Çünkü sağlığın nasıl kavramsallaştırıldığı, kullanılan cevapların türleri üzerinde derin etkiler yaratacaktır. Tarihsel olarak, kamu malları için kolektif eylem elde etmek zor olmuştur. Küresel kamu malları kavramı, ortak ihtiyaca dayalı olarak kolektif eylemler için bir çerçeve sağlamaya çalışır. Bununla birlikte, küresel kamu malları kavramı, haklara ya da insan sağlığına dayalı bir politika modelini geliştirmek için çok az şey yapmaktadır. Küresel sağlık işbirliğine yönelik alternatif çerçeveleri araştıran sağlık kavramlarının yanı sıra, uluslararası normatif düzen sırasındaki çeşitli söylemlerin çıkarlarını sorgulayan eleştirel teoriler de dâhil olmak üzere, küresel sağlık işbirliğinin yeni kavram ve teorilerine ihtiyaç vardır.

Özel vakıfların (örn. Bill \& Melinda Gates) ve KKÖSI’lerin (örn. GFATM, GAVI) küresel sağlık ortamındaki önemli payı kuşkusuz devam etmektedir. Artan sayıdaki "dikey" girişimlerin ürettiği parçalanma, belirli hastalıkların tedavisi için ilaç ve hizmetlere ulusal düzeyde erişimi kolaylaştırıyor gibi görünse de, sağlık hizmetlerindeki sürekliliği zedelemektedir. Çoğulculuk ve ulusal sağlık planlarına uyumsuzluktan kaynaklanan sorunlar, gözlemciler arasında bu yaklaşımın etkinliği ve uygunluğu konusunda artan kuşkuları doğurmuştur.

Sürdürülebilirlik, adalet ve eşitlik konularındaki sorunlar, yüksek düzeyde finansman ihtiyacı ve hızlı sonuç beklentileri hem küresel hem de ulusal düzeydeki yapılanmaları zora sokmaktadır. Örneğin; GAVI'nin başlangıcında, GAVI finansmanı öncesinde temel aşı kapsamı dışında kalan çocukların bu şekilde devam edeceği ve yeni aşılara erişemeyeceği yönünde ciddi endişeler ortaya çıkmıştır. Yeni ve daha pahalı aşılar, ülke düzeyinde bağışıklama programlarının maliyetlerini yükseltmiş ve programların gelecekteki finansmanını son derece riskli bir hale getirmiştir.

Küresel sağlık politikalarını geliştirme yaklaşımları ile sağlık politikaları giderek daha fazla parçalanmış ve dikeyleştirilmiştir. Bu durum, müdahale edilecek hastalıkların seçilmesine, artan sayıda işbirliklerine ve özellikle de çeşitli sağlık sorunlarına yönelik yeni kurumların kurulmasına bağlı olarak derinleşen bir sorun halini almaktadır. Bu eğilimler, sağlık politikası oluşturmanın daha geniş kalkınma gündemi veya kapsamlı sağlık sektörü planlaması ile entegre edilmesi amaçları ile çelişmektedir. Çalışmamızda, birbiriyle bağlantılı olan bu faktörler arasındaki denge eşleştirilmeye çalışılmış ve "herkes için sağlık" açısından, WHO'nun orijinal görevini ve yetkisini geri kazanmasına izin verilmesi gerektiği önerilmiştir.

\section{Kaynakça}

Acartürk, E. \& Keskin, S. (2012). “Türkiye' de Sağlık Sektöründe Kamu Özel Ortaklığı Modeli”, Süleyman Demirel Üniversitesi İktisadi ve İdari Bilimler Fakültesi Dergisi, 17(3), 25-51.

Barr, D. A. (2007). "Ethics in Public Health Research: A Research Protocol to Evaluate the Effectiveness of Public-Private Partnerships as a Means to Improve Health and Welfare Systems Worldwide", American Journal of Public Health, 97, 19-25.

Besley, T. \& Ghatak, M. (2007). "Reforming Public Service Delivery", Journal of African Economies, 16 (1), 127-156. 
Brown, S. (2008). Global public-private partnerships for pharmaceuticals: operational and normative features, challenges, and prospects. Retrieved from: http://www.eisanet.org/bebruga/eisa/files/events/turin/Brown-Sherri\%20Brown\%20Turin\%202007.pdf, (04.02.2019).

Boz, S. S. (2013). "Kamu Özel İşbirliği Modeli”, İnönü Üniversitesi Hukuk Fakültesi Dergisi, 4(2), 277-332.

Buse, K. \& Walt G. (2000a). "Global Public Private Health Partnerships: Part II What Are the İssues for Global Governance?", Bulletin of the World Health Organization, 78 (5), 699-709.

Buse, K. \& Walt, G. (2000b). “Global Public-Private Partnerships: Part I - A New Development in Health?", Bulletin of the World Health Organization, 78 (4), 549-561.

Buse, K. \& Harmer, A.M. (2007). "Seven Habits of Highly Effective Global Public-Private Health Partnerships: Practice and Potential", Social Science \& Medicine, 64, 259-271.

Dodgson, R., Lee, K. \& Drager, N. (2002). Global Health Governance. A conceptual Review, Discussion paper n.1, LSHTM - WHO, February.

Ertürk Atabey, S. (2012). Sağlık Sistemleri ve Sağlık Politikası, Ankara: Gazi Kitabevi.

Johnson, S. A. (2017). Challenges in Health and Development From Global to Community Perspectives, Second Ed., Springer International Publishing, ISBN 978-3-319-53203-5 ISBN 978-3-319-53204-2 (eBook), (01.02.2019).

Gediz Oral, B. (2014). “Sağl1k Hizmetlerinin Küresel Kamusal Mal Olarak Değerlendirilmesi: Uluslararası Örgütler", Finans Politik E Ekonomik Yorumlar, 51 (588), 79-96.

Gediz Oral, B. (2016a). "Sağlık Hizmetleri Arzında Bir Alternatif: Kamu Özel Sektör İşbirlikleri", Uluslararası Stratejik Araştırmalar Kongresi, ISBN 978-975-8628-48-3, 631-639.

Gediz Oral, B. (2016b). "Marketization of Health Sevices, An Alternative Supply of Health Services: Public Prive Partnerships in Turkey", 2016 Sosyo-Economic Strategies, Ed. Ali Riza Gökbunar, Birol Kovancilar, Selim Duramaz, Germany: Lambert Academic Publishing, ISBN: 978-3-330-00679-9, 135-16.

Gediz Oral, B. \& Arpazlı Fazlılar, T. (2018). “Sağlık Odaklı Küresel Kamu Özel Sektör İşbirlikleri”, Maliye Araştırmaları -2, Ed. Selçuk İpek, E-ISBN: 978-605-327-740-8, Ekin Yayınevi, Bursa, 315-336.

Gürkan, M. F. (2014). Kamu Özel Ortaklı̆̆ı, Ankara: Adalet Yayınevi.

Karahanoğulları, Y. (2012). "Kamu Özel Ortaklığı Modelinin Mali Değerlendirmesi”, Ankara Üniversitesi SBF Dergisi, 67(2), 95-125.

Kirmanoğlu, H., Yılmaz, B. E. \& Susam, N. (2006). “Maliye Teorisinin Çıkmazı Küresel Kamusal Mallar (Kalkınma Yardımları İçinde Küresel Kamusal Malların Finansmanı)", 21. Türkiye Maliye Sempozyumu: Kamu Maliyesinde Güncel Gelişmeler, Çanakkale Onsekiz Mart Üniversitesi, Biga İktisadi ve İdari Bilimler Fakültesi, 10- 14 Mayıs, Antalya.

Missoni, E. (2008). "Who Governs World Health?", http://www.eduardomissoni.net/CV/mieiscrittipdf/080926\%2020Who_Governs_World_H ealth_Martigny.pdf, (10.02.2019). 
Missoni, E. \& Pacileo G. (2015). "Global Public-Private Partnerships", https://www.aeonprime.net/pdf-2-1-3-global-public-private-partnerships-eduardomissoni-guglielmo-pacileo.html, (25.02.2019).

Nordhaus, W. D. (2005). "Paul Samuelson and Global Public Goods", Review literature and arts of the Americas, 36(4), 387-389.

Ollila E. (2005). "Global Health Priorities - Priorities of the Wealthy?", Global Health, 1, 610.1186/1744-8603-1-6, (04.04.2018).

Rangan, S., Samii, R., \& Van Wassenhove, L. N. (2006). “Constructive Partnerships: When Alliances between Private Firms and Public Actors Can Enable Creative Strategies", Academy of Management Review, 31(3), 738-751.

Sarısu, A. (2008). "Altyapı Yatırımlarında Kamu ve Özel Sektör İşbirlikleri-I”, Yaklaşım Dergisi, 181, 199- 205.

Schomaker, R. M. (2017). "Public-Private Governance Regimes in the Global Sphere", Public Organization Review, 17(1), 121-138.

Smith, R. D. \& MacKellar, L. (2007). "Global Public Goods and the Global Health Agenda: Problems, Priorities and Potential", Globalization and Health, 3(9) http://www.globalizationandhealth.com/content/3/1/9, (15.02.2019).

Smith, R.D. (2003). "Global Public Goods and Health", Bulletin of the World Health Organization, $81(7), 475$.

Stiglitz, J. E. (1994). Kamu Kesimi Ekonomisi, Çev. Batırel, Ö .F., 549, İ̈BF Yayın No: 396, İkinci Bask1, İstanbul: Marmara Üniversitesi Yayınları.

Şahin, M. \& Uysal, Ö. (2012). “Kamu Maliyesine Etkileri Açısından Kamu Özel Sektör Ortaklıkları Üzerine Bir Değerlendirme”, Maliye Dergisi, 162, 155- 174.

Topkaya, Ö. (2016). "Sosyal Politika Bağlamında Dünyada Sağlık Politikalarının Tarihsel Gelişimi", Süleyman Demirel Üniversitesi İ̈BF Dergisi, 21(2), 707-722.

Türmen, T. (1999). “Making Globalization Work for Better Health”, Development 42(4), 8-11.

Walt, G. (1998). “Globalization of International Health”, Lancet, (351), 434-437.

Woodward D, Drager N, Beaglehole R. \& Lipson, D. (2001). “Globalisation and Health: A 22 Framework for Analysis and Action", Bulletin of the World Health Organization, 79, 875-881.

Yalçın, A. Z. (2009). “Küresel Çevre Politikalarının Küresel Kamusal Mallar Perspektifinden Değerlendirilmesi”, Balıkesir Üniversitesi Sosyal Bilimler Enstitüsü Dergisi, 12 (21), 288-309.

\section{Açıklamalar}

1. Türk literatüründe Public Private Partnerships (PPPs- 3P) kavramının karşıllığ1 olarak; Kamu-Özel Sektör İşbirliği (Sarısu, 2008), Kamu-Özel Sektör Ortaklığı (Şahin-Uysal, 2012), Kamu-Özel İşbirliği (Boz, 2013), Kamu-Özel Ortaklığı (Gürkan, 2014), Kamu Özel Ortaklığı Modeli (Acartürk-Keskin, 2012), eksik imtiyaz (Karahanoğulları, 2011) gibi kavramlar kullanılmaktadır. Biz Kamu Özel Sektör İşbirliği kavramını kullanmayı tercih ediyoruz. 
2. Burada ikili bağışçılar veya "iki taraflı yardım" kavramı, ilgili desteğin doğrudan hükümete sağlanmasını ifade eder. ABD iki taraflı yardımların yaklaşık 1/3'ünü sağlamaktadır. Küresel sağlık politikası ortamında ABD'nin rolü 1990'larda artmıştır. ABD, aynı zamanda AB'nin başlangıçta daha kritik olduğu GFATM'nin (AIDS Tüberküloz ve Sitma ile Mücadelede Küresel Fon) oluşturulmasında da etkili olmuştur. Bu süreçte, ABD dış politikası UN gibi uluslararası kurumlar aracılığıyla hareket etmeye veya ortak hedeflere ulaşmak için diğer milletlerle işbirliği içinde çalışmaya daha az meyilli olmuştur (Ollila, 2005). UN, WB, WHO gibi kuruluşların dâhil olduğu çok taraflı yardımlarda ise bağışlar bir havuzda toplanır ve yardım buradan gerçekleştirilir.

3. İnsan sağlık sistemi tarafından bilinmeyen, insandan insana kolayca bulaşabilen ve bu nedenle tüm dünyaya yayılma riski olan viral hastalıklardır.

\section{Birleşmiş Milletler Nüfus Fonu}

5. WHO, KKÖSİ için ilkeleri ve çalışma çerçevesini tanımlamak üzere bir Çalışma Grubu oluşturmuştur. Temel etik ilkeler; yararlanma, zararsızlık, özerklik ve eşitliktir (Buse ve Walt 2000a). Bunlar, tıp alanını destekleyen etik ilkelerle aynı ilkelerdir. WHO ortaklıklarının çerçevesi açısından, Çalışma Grubu, WHO'nun tarafsız bir sağlık otoritesi olarak itibarını korumanın ve ortaklık faaliyetlerinin uygunluğunu önemli endişeler olarak değerlendirmenin ve potansiyel çıkar çatışmalarını azaltmaya yönelik önerilen prosedürleri belirleme ihtiyacını vurgulamaktadır (Buse ve Walt, 2000a). WHO'nun işbirliği için kılavuz ilkeleri, KKÖSİlerin WHO Etik Kurulu ve Kamu Sektörü İşbirliği Komitesi tarafından gözden geçirilmesine ilişkin hükümler içermiştir (Johnson, 2017: 181).

6. Dodgson vd. (2002) yönetimi yönetişimden ayırır ve yönetişimi "ortak hedefler doğrultusunda kollektif eylemleri teşvik etmek ve ortak çözümler sunmak için bir toplum tarafından benimsenen eylemler ve araçlar" olarak tanımlamaktadır. Yönetişim, ortak sosyal hedefler ve amaçlar doğrultusunda resmi veya gayri resmi faaliyetler ve mekanizmalardır (Missoni, 2008). 